\title{
KONSTRUKTIVISTICKÉ PŘÍSTUPY V NĚMECKÉ MUZEJNÍ EDUKACI NA PŘÍKLADU DVOU TZV. NOVÝCH PRŮMYSLOVÝCH MUZEI' ${ }^{1}$
}

\section{MONIKA KUDELOVÁ}

\section{ABSTRAKT/ABSTRACT:}

S konstruktivistickou teorií vzdělávání jako způsobem efektivnějšího a smysluplného učení a z principu tedy protipólem $\mathrm{k}$ transmisivnímu edukačnímu př́stupu přichází $\mathrm{v}$ polovině 20. století švýcarský psycholog Jean Piaget a francouzský filosof Gaston Bachelard. Zatímco je poznání do té doby považováno za nezávislé na lidském myšlení a ke vzdělávajícímu se jedinci žákovi se přistupuje jako $\mathrm{k}$ nepopsanému listu papíru, konstruktivismus razí myšlenku (re)konstruování poznatků na základě předchozích představ, znalostí a zkušeností. Žák již není pasivním př́ijemcem informací, ale hlavním aktérem učení. Integrace konstruktivistických myšlenek do muzejní edukace je pomalá, avšak ne nezaznamenatelná.

\section{Podle George Heina zatím} neexistuje ryze konstruktivistické muzeum. Přesto u mnoha moderních světových muzeí jsou konstruktivistické prvky patrné nejen ve specifických výchovně-vzdělávacích programech určených konkrétním cílovým skupinám, zejména školám, ale také v samotných expozicích využívajících moderního scénografického designu. Pro ilustraci praktické aplikace

1 Tato studie vznikla v rámci řešení projektu SGS05/FF/2019-2020 Možnosti využití tématu každodennosti moderní doby ve výuce dějepisu na Ostravské univerzitě. konstruktivistického pojetí muzejní edukace příspěvek analytickodeskriptivním způsobem přibližuje specifika dvou edukačních programů, realizovaných pro školní skupiny přibližně stejné věkové kategorie ve vybraných německých tzv. nových průmyslových muzeích - LWL Industriemuseum Textilwerk Bocholt a LVR Industriemuseum Zinkfabrik Oberhausen.

Constructivistic approaches in the German museum education on the example of two so-called new industrial museums

In the middle of the 20th century, the Swiss psychologist Jean Piaget and the French philosopher Gaston Bachelard came up with the constructivist theory of education as a way of more effective and meaningful learning and, in principle, as a counterpart to the transmissive education approach. While knowledge was until then considered independent of human thought and the learner was treated as a blank sheet of paper, constructivism pursues the idea of (re)constructing knowledge based on previous ideas, knowledge and experience. The student is no longer a passive recipient of information, but the main actor in learning. The integration of constructivist ideas into museum education is slow, but not unnoticeable.

According to George Hein, there is no purely constructivist museum yet. Nevertheless, in many modern world museums, constructivist elements are evident, especially in specific educational programs, but also in the exhibitions themselves, using modern scenographic design. To illustrate the practical application of the constructivist concept of museum education, the paper presents in an analyticaldescriptive way the specifics of two educational programs implemented for school groups of approximately the same age category in selected German so-called new industrial museums - LWL Industriemuseum Textilwerk Bocholt and LVR Industriemuseum Zinkfabrik Oberhausen.

\section{KLÍČOVÁ SLOVA/KEYWORDS:}

muzejní pedagogika -

konstruktivismus - německá tzv. nová průmyslová muzea - pracovní listy - muzejní didaktika museum pedagogy - constructivism German so-called new industrial museums - worksheets - museum didactics

\section{Úvod}

Muzeu jako instituci, která sbírá, uchovává, ochraňuje a vystavuje předměty lidské historie či prrírodní artefakty, byla vždy přisuzována také funkce výchovná a vzdělávací. Pohled na důležitost a podobu této funkce se však $\mathrm{v}$ různých zemích a muzeum od muzea od počátku jejich existence lišil. 
Za kolébku muzejní edukace a potažmo i teoretického vědního oboru, dnes etablovaného jako muzejní pedagogika, je považováno německé prostředí. Zde již na počátku 19. století působili v některých muzeích reformní pedagogové, kteří svými inovátorskými, didaktickými, filosofickými i psychologickými myšlenkami a praktickými metodickými náměty ovlivňovali tvář muzejních expozic a muzejních programů, orientovaných na školní děti a mládež jako jednu z cílových skupin návštěvníků. ${ }^{2}$

Seznámíme-li se s konkrétními díly a myšlenkami těchto reformních pedagogů, zjistíme, že se v nich do jisté míry objevují názory korespondující s moderní, dnes stále více diskutovanou teorií učení a poznávání, která nepovažuje vzdělávajícího se jedince za nepopsaný list papíru a pasivního prríjemce informací, ale za tvůrčí osobnost konstruující vědění ve vlastní mysli, zasluhující vzdělávací podmínky, podporující jejich aktivní participaci a rozvíjející celkovou osobnost. Hovoříme o konstruktivistické teorii, jež je v kontextu muzejní edukace meritem předkládané stati.

Dříve, než zaměříme pozornost na klíčové aspekty konstruktivismu a jejich translaci do prezentační didaktiky převážně edukačních programů pro školní skupiny, představme alespoň jednoho z oněch německých „reformátorů“, který zásadním způsobem ovlivnil edukační funkce prvního německého technicko-

\footnotetext{
2 Z českých přehledů viz JŮVA, Vladimír. Vývoj německé muzeopedagogiky. Brno: Paido, 1994 $\mathrm{Z}$ německých prací viz GEBHARD, Julius. Alfred Lichtwark und die Kunsterziehungsbewegung in Hamburg. Hamburg: Hoffmann und Campe, 1947; Karl Ernst Osthaus - Leben und Werk. Recklinghausen: Bongers, 1971; JOACHIMEDES, Alexis. Die Museumsreformbewegung in Deutschland und die Entstehung des modernen Museum 1880-1940. Dresden: Verlag der Kunst, 2001; VIEREGG, Hildegard. Geschichte des Museums, eine Einführung. München: Wilhelm Fink Verlag, 2008.
}

průmyslového muzea - Muzea mistrovských děl techniky a přírodních věd v Mnichově Georga Kerschensteinera.

V městské kronice bavorského města Mnichov se $\mathrm{k}$ roku 1932 objevuje krátká zpráva o úmrtí osmasedmdesátiletého pedagoga a školního reformátora Georga Kerschensteinera (1854-1932), který v letech 1895 až 1919 působil jako městský školský rada zodpovědný za celý mnichovský školský systém. Zásluhy jsou mu zde přičítány v zavádění řady nových opatření. Rozmanitost jeho myšlenek pedagogicko-didaktických principů a bez nadsázky i jisté filosofie reformního vzdělávání je shrnuta v jediné větě vystihující podstatu veškerého výchovně-vzdělávacího úsilí: „boj proti jednostranné intelektualizaci (Intelektualisierung) a podpora výchovy celkové osobnosti člověka“, již se snažil aplikovat nejen ve školství, ale rovněž v mimoškolním prostředí. Za zcela průkopnickou je v této oblasti považována jeho koncepce praktických škol odborného vzdělávání, které se staly předchůdci dnešních Berufsschulen.

Myšlenka zavedení praktických škol, které by se nezaměřovaly pouze na intelektuální výkon žáki̊, ale rozvíjely schopnosti a dovednosti žáků pro případné jejich budoucí povolání, se jistým způsobem odrazila $\mathrm{v}$ dalším $\mathrm{z}$ jeho vysoce oceňovaných reformních počinů - pedagogicko-didaktické koncepci nově zakládaného Muzea mistrovských děl techniky a přírodních věd $v$ Mnichově, $v$ níž vymezil jeho vzdělávací úkoly. ${ }^{3}$

\footnotetext{
3 KERSCHENSTEINER, Georg. Die Bildungsaufgabe des Deutschen Museums. In MATSCHOSS, Conrad (ed.). Das deutsche Museum, Geschichte, Aufgaben, Ziele; im Auftrage des Vereines Deutscher Ingenieure unter Mitwirkung hervorragender Vertreter der Technik und Naturwissenschaften. Berlin: VDI Verlag, München: R. Oldenbourg, 1925, s. 39-50.
}

V úvodu vymezuje edukační roli muzea, kde píše, že „má-li muzeum sloužit vzdělávacím účelưm, musí celá jeho struktura vnitřního ,designu'vycházet z pedagogických principů, avšak aniž by opomíjela ostatní aspekty vědecké, estetické, sociální či historické povahy." Dále pak takřka ztotožňuje muzeum se školou: „pokud se muzeum neorientuje pouze na návštěvníky, milující zábavu, pak může být muzeum školou, ovšem ne $v$ tradičním smyslu pouhého přenosu znalostí a dovedností. Skutečný vzdělávací proces musí mít hlubši záměr: ovlivňovat mentální strukturu návštěvníků prostřednictvím zkoumání, prožívání hodnot."4 Z uvedeného je patrná jednoznačná blízkost soudobého konstruktivistického pojetí muzejní edukace, jak věřím, vyplyne z hlavní části práce. Z celkem osmi jádrových principů, jež Georg Kerschensteiner blíže specifikuje, uved'me pro ilustraci ještě poslední, asi nejznámější citát: ${ }^{5}$ „Nutno pracovati s věcmi samotnými a nikoli s jejich stíny. "6

Jistě bychom mohli ve výčtu Kerschensteinerových doporučení, blízkých námi sledované edukační teorii, pokračovat dále. Cílem této stati ovšem je přiblížit hlavní myšlenky samotného konstruktivismu, a to jak v rámci teoretického vymezení a kategorizace edukačních teorií, tak především jejich aplikace do muzejně-pedagogické praxe na konkrétním prríkladu dvou edukačních programů,

\footnotetext{
4 Tamtéž.

5 Z českých prací, které se jen okrajově zmiňují o Georgu Kerschensteinerovi v rámci vývoje německé muzejní pedagogiky, se uvedený citát rovněž objevuje např. v JÜVA, Vladimír. Vývoj německé muzeopedagogiky. Brno: Paido, 1994 6 KERSCHENSTEINER, Georg. Die Bildungsaufgabe des Deutschen Museums. In MATSCHOSS, Conrad (ed.). Das deutsche Museum, Geschichte, Aufgabe, Ziele. im Auftrage des Vereines Deutscher Ingenieure unter Mitwirkung hervorragender Vertreter der Technik und Naturwissenschaften. Berlin: VDI Verlag, München: R. Oldenbourg, 1925, s. 39-50.
} 
realizovaných $\mathrm{v}$ tzv. nových průmyslových muzeích.

\section{Muzejní edukace na křižovatce teorie poznávání a učení}

$\mathrm{V}$ průběhu historie se vyvíjela řada teorií, jakožto „více či méně systematizovaných souhrnů idejï", vztahujících se ke způsobům poznávání a učení. Toto množství souhrnů bylo mnohými autory různými způsoby klasifikováno a zpřehledněno pro jejich snadnější selekci a využití v samotné praxi.

Pro muzejně edukační prostředí poskytl zajímavou klasifikaci George Hein, systematicky a smysluplně koncipovanou ve formě diagramu. Ten znázorňuje rovinu edukačních teorií, která je rozdělena do čtyř sektorů osou X teorií učení a osou Y teorií poznávání. Autor tak vymezuje oblasti edukačních teorií tradičních, objevových (discovery), behavioristických a konstruktivistických. Tyto oblasti jsou generované jako průniky limit teorie učení a teorie poznávání. Epistemologické limity na kladné a záporné ose Y Heinova diagramu jsou vyjádřeny slovy „poznatky existující mimo žáka" (tuto teorii zastával např́iklad Platon) a „poznatky konstruované $v$ žákově mysli“ (jedním z př̀edstavitelů byl Berkeley). Dichotomie teorie učení je reprezentována rovněž dvěma extrémními případy, zde souvisejícími s lidskou psychologií učení, tedy způsoby, jak se učíme „tradiční učeni" ve formě předávání poznatků učitelem žákovi, který je vnímán jako „tabula rasa“ (viz John Lock) a „učení konstruované" v mysli žáka, rozvíjejícího přitom rozmanité myšlenkové procesy (viz Jean Piaget). ${ }^{8}$

\footnotetext{
7 BERTRAND, Yves. Soudobé teorie vzdělávání Praha: Portál, 1998.

8 HEIN, George E. The constructivist museum. In HOOPER-GREENHILL, Eilean. The Educational Role of the Museum. London, New York: Routledge, 1994, s. 76-77.
}

Tradiční edukační teorie, již Hein označuje výrazy ,tradiční lekce a text", vychází z názoru o poznávání absolutním, existujícím a měnícím se nezávisle na žácích. Žák je zde chápán jako „tabula rasa“, pasivní př́ijemce a „hromaditel“" vně existujících poznatků. $\mathrm{V}$ praxi se jedná o př́stup charakteristický monologickým přednášením vyučujícího, minimálním zapojením žáků, jednoduchými úkoly v podobě nekritické četby textu a prázdného memorování. Přeneseno do muzejního prostředí, omezuje se nabídka pro školy na běžné komentované prohlídky expozic $\mathrm{s}$ objekty $\mathrm{v}$ prosklených vitrínách a informační tabule jako jediného didaktického prostředku. ${ }^{9}$

Rovněž edukační teorie objevová (discovery learning) je založena na pozitivistickém názoru, že poznatky existují vně žáka, který je však oproti tradiční teorii aktivně zapojen do jejich osvojování. Má pozorovat, měřit, zobecňovat a získávat zkušenosti. Místo čistě verbálních metod jsou preferovány metody s vysokou mírou názornosti, $\mathrm{v}$ muzeích zejména princip handson, objektové a zážitkové učení a formu prohlídky nahrazují tematické lekce $\mathrm{v}$ učebnách a praktické činnosti v tvůrčích dílnách či workshopech.

\section{Odlišný přístup se pojí} s edukačními teoriemi ve spodní části diagramu. Představitelé behavioristické teorie již pracují se skutečností, že poznatky mohou vznikat závisle na myšlení žáků, třebaže tyto jsou, shodně s názory tradiční edukační teorie, hromaděny přirůstajícím způsobem osvojování.

Nejzásadnější změny v pohledu na poznávání a učení přináší konstruktivistická edukační teorie opírající se o idealistickou

9 Tamtéž. epistemologii, vývojovou psychologii a soudobé výzkumy pedagogické psychologie. Autoři konstruktivismu předpokládají, že jak způsob osvojování, tak i poznatky samotné jsou závislé na myšlení žáků. V průběhu učení žáci nové poznatky „nepřičítaji“ $\mathrm{k}$ již dříve osvojeným, ale v interakci s okolím zasazují do svých koncepcí, které restrukturují a rozmanitými myšlenkovými operacemi tak v podstatě poznatky vytvářejí. Tyto poznatky se nevyvíjejí mimo myšlení jedince a mají povahu individuální nebo sociální. ${ }^{10}$

\section{Exkurz do teorie konstruktivismu}

Dříve, než se zaměříme na obraz konstruktivistického muzea, jak jej nastiňuje George Hein, věnujme několik odstavců samotné konstruktivistické teorii.

Konstruktivismus se „na scénu“ teorií o vzdělávání dostává v polovině 20. století jako kognitivně psychologický proud díky švýcarskému psychologovi Jeanu Piagetovi a francouzskému filosofovi Gastonu Bachelardovi, na něž navázali další badatelé ve Francii, Švýcarsku, ale i v severní Americe. Hlavní témata stoupenců piagetovské teorie se opírala o Piagetem vymezená vývojová stádia dítěte a interakce, jimiž jedinec konstruuje své poznání a na základě nichž reguluje své chování, jenž přizpůsobuje okolnímu světu.

V oblasti epistemologie sehrály klíčovou úlohu práce Bachelardovy, objasňující význam překážek poznávání v učení. Právě Bachelard přišel s onou razantní změnou v pohledu na žáka, který již není chápán jako prázdná nádoba určená k plnění, ale jako kognitivně aktivní jedinec, který přichází do třídy $\mathrm{s}$,hotovými empirickými poznatky“. Podle této teorie má každá

10 Tamtéž. 
osoba „určitou vědeckou kulturu“ utvářenou re-konstruováním současných poznatků a zkušeností „v jistých stádiích od naivního realismu $k$ diskurzivnímu racionalismu“. ${ }^{11}$

Smyslem učení potom není osvojit si vědeckou kulturu jako takovou, ale přejít do jiného typu, tj. z pojetí jedince do vědeckého pojetí a odstranit tak překážky, tedy omyly, „nahromaděné každodenním životem". ${ }^{12}$ Proces poznávání zde na rozdíl od ontologického nebo realistického konceptu není chápán jako „věrné reprezentování vnějšího světa, toho, co existuje mimo lidskou mysl“",13 naopak sám vzdělávající se jedinec je oním tvůrcem, konstruktérem poznatků, tím, kdo realitu vytváří. ${ }^{14}$

Konstruktivistické myšlenky, $\mathrm{z}$ počátku formované $\mathrm{v}$ teorii učení, se postupně přenášely do širší oblasti vzdělávání a konstruktivismus začal být mimo jiné chápán také jako „teorie utváření vědomostí žáka a vědeckých poznatkư". 15

Výchozím bodem pro didaktický přístup k utváření žákových vědomostí se stal konstruktivisty zavedený pojem, v českém prostředí nejčastěji překládaný termíny „„̌ákovo pojetí“, „,̌áákova interpretace“ či „žákovy prekoncepty“. Ve skutečnosti se jedná o dva významově se lišící pojmy. Zatímco pojmem „žákovo pojetí“ (u zahraničních autorů „student's concept“ nebo

\footnotetext{
11 BERTRAND, Yves. Soudobé teorie vzdělávání. Praha: Portál, 1998.

12 Tamtéž.

13 MATURANA, Humberto R. a Francisco J. VALERA. Der Baum der Erkenntnis: Die biologischen Wurzeln des Menschlichen Erkennens. München: Goldmann, 1990.

14 Maturana a Varela tento proces tvorby označují pojmem „ontování“ - utváření jsoucího světa (pozn. aut.).

15 GEELAN, David R. Epistemological Anarchy and the Many Forms of Constructivism. Science and Education, 1997, roč. 6, č. 1, s. 15-28.
}

„student's understanding“) se rozumí komplexní (ne nutně verbalizovatelné) chápání určitého jevu jedincem, zahrnující prekoncepty, koncepty, mylné koncepty (miskoncepce), mentální mapy a emocionální prožitky, spojené s daným jevem, pojmem „prekoncept“ (v cizojazyčné literatuře spíše „naive theory“) jsou označovány jedincovy představy jako „soustava organizovaných pojmů s různým uspořádáním a hierarchickou strukturou“" vytvářené obdobným způsobem, jako u vědeckých teorií, které zrovna tak něco popisují, explanují (vysvětlují), predikují (předvídají) nebo poskytují návod k činnosti. ${ }^{16}$

Podle Bachelardem inspirovaných badatelů M. Larochella a J. Desautelse lze prekoncepty (tito autoři používají termín ,spontánní koncepty") chápat jako jakýsi neustálý srovnávací systém, v němž jedinec, žák transformuje nové, jemu zprostředkovávané poznatky do své uchopitelné a pro něj srozumitelné pojmové podoby, tyto konfrontuje s již dříve osvojenými a na základě jejich souvislostí je mezi ně začleňuje nebo jimi původní strukturu přetváří a nakonec osvojuje. Objasněné doplňuje další z Bachelardových nástupců A. Giordan explanací, že součástí tohoto systému jsou „dekódovací struktury, které dávají význam nashromážděným informacím, a prijímací struktury, které prípadně umožní zabudovat nová fakta“. ${ }^{17}$

Čím tedy žákovy prekoncepty jsou? Jak píše Giordan a jiní, nejsou ani odrazovými můstky v procesu konstruování vědomostí ani jeho výsledkem. Prekoncepty

\footnotetext{
16 ŠKODA, Jiří a Pavel DOULÍK. Dětská pojetí: teoretická východiska a metodologické aspekty. In JANÍKOVÁ, Marcela a Kateřina VLČKOVÁ. Výzkum výuky - tematické oblasti, výzkumné př́stupy a metody. Brno: Paido, 2009, s. 117-143. 17 BERTRAND, Yves. Soudobé teorie vzdělávání. Praha: Portál, 1998.
}

sehrávají roli samotného a pro žáka ve skutečnosti jediného nástroje v poznávací činnosti, pomocí kterého dekóduje a osvojuje realitu, a který mobilizuje a přizpůsobuje vždy v závislosti na konkrétních situacích, jichž je součástí.

Další z pojmů, s nimiž

konstruktivisté pracují, a které úzce souvisí s prekoncepty, jsou pojmy „pedagogický profil “ a „metakognice“. Z výzkumů Antoina de la Garanderie je známo, že každý žák disponuje určitými schopnostmi, konkrétními metodami a způsoby, jimiž pracuje $s$ informacemi. A právě tyto navyklé postupy práce formují pedagogický či epistemologický profil žáka, to jest žákovu kognitivní charakteristiku. Samotný termín Garanderie přibližuje hezkým srovnáním s profilem vědce: „A vskutku jsem zjištoval, že myšlení mých žáků nebylo žádná tabula rasa in qua nihil scriptum. Měli nějakou zkušenost, prefilosofii, která byla implicitní, avšak obsahovala intuitivní názory podporované rozptýlenými a prchavými argumenty, to vše vytvářelo jakési pedagogické nevědomí - či predvědomí. [...] jsou-li vědci poznamenáni svými kulturními zkušenostmi natolik, že nevědomky upřednostňuji realistické, romantické nebo pozitivistické ideje [...] atd., proč by i žáci, kteři také nejsou bez zkušenosti získaných četbou či z každodenního života, neměli také jistý profil, který bychom mohli nazvat pedagogickým?" Tento pedagogický profil však obdobně jako u vědců jmenované upřednostňování jedné či více idejí před jinými představuje v jistém smyslu překážku, v případě žáka epistemologickou, která zabraňuje kognitivnímu či celkově mentálnímu rozvoji, v cestě za novým poznáním. ${ }^{18}$

18 Tamtéž. 
Aby se podařilo tyto překážky překonat, měly by být $v$ procesu učení vytvořeny podmínky, které žákovi umožní si nejen uvědomovat, ale i promýšlet, regulovat, hodnotit a obměňovat vlastní postupy poznávání a učení. Tato způsobilost jedince chápat a reorganizovat svůj původní pedagogický profil je v konstruktivistické literatuře nazývána pojmem „metakognice“, jejíž součástí jsou tř̌i základní koncepty: metakognitivní poznatky, metakognitivní monitorování a regulování, metakognitivní uvědomění či pojetí. Metakognitivními poznatky se rozumí znalost jedince jeho vlastních „poznávacích procesů, podstaty učení a efektivních učebních metod“. Druhý koncept se pojí se schopností monitorovat a řídit průběh těchto poznávacích procesů. Nakonec třetí koncept představuje obecné ideje a teorie, které má žák o svém způsobu poznávání.

Uvedené pojmosloví se stalo základem jak individuálního, tak sociálního konstruktivismu. Teorie individuálního konstruktivismu je dosud nejpropracovanějším a empiricky doloženým typem. ${ }^{19}$ V současné době se hovoří o radikálním individuálním konstruktivismu, za jehož zakladatele je považován E. von Glaserfeld, přičemž detailněji jej do teorie rozpracovali Maturana a Varela. Jak píše Ondrej Kaščák ve své stati, Maturana a Varela byli prvními, kdo poukázali na skutečnost neschopnosti organismu přijímat informace jako hotové významy zvenku, tyto se vytvárí dle nich teprve v interním celulárním systému. Významy a následné chování jedince jsou pak výsledkem vlastního procesu strukturování, nikoliv vnějších podnětů,

19 WHEATLEY, Grayson H. Constructivist Perspectives on Science and Mathematics Learning. Science Education, 1991, roč. 75, č. 1, s. 9-21. médií. ${ }^{20}$ Podle G. Rotha, jednoho ze současných představitelů radikálního individuálního konstruktivismu, do mozku putují nanejvýš informace o intenzitě podnětů a samotný význam je legitimován mozkovými centry. Stimuly zvenčí v důsledku sehrávají roli spouštěčů kognitivní aktivity. Současně Roth tvrdí, že vztah člověka a prostředí nelze vyjádřit pouhou triviální rovnicí akce (podnět) vyvolá reakci, nebở jedinec (organismus) je schopen spontánní aktivity i bez vnějších stimulů. ${ }^{21}$

Vyvstává otázka, jak probíhá vzájemná komunikace a interakce mezi jedinci, tedy ve společnosti.

Podle konstruktivistické empiricky doložené teorie nedochází $\mathrm{k}$ přenosu či výměně informací mezi komunikátorem a komunikantem, tito se „navzájem podněcují ke konstrukci informací.“22 Podněty ke komunikaci, jakož i významy konstruované a strukturované v mozku jedinců, nemusí být u všech zúčastněných shodné. Přenesemeli tato tvrzení do prostředí edukace, je tato skutečnost také důvodem, proč frontální výuka nebo jakkoli modifikovaná hromadná komentovaná prohlídka nemá očekávaný účinek. Dle Kupferra již pedagog nemůže „počítat s tím, že ho jisté činnosti, rozhodnutí či výchovní styly

\footnotetext{
20 KAŠČÁK, Ondrej. Je pedagogika připravená na změny perspektiv? Rekontextualizace pohledů na výchovně-vzdělávací proces pod vlivem radikálního individuálního konstruktivismu a postmoderního sociálního konstruktivismu. Pedagogika, 2002, roč. 52, č. 4, s. 388-414.

21 ROTH, Gerhard. Das konstruktive Gehirn: Neurobiologische Grundlagen von Wahrnehmung und Erkenntnis. In SCHMIDT, Siegfried J. (ed.). Kognition und Gesellschaft. Der Diskurs des Radikalen Konstruktivismus II. Frankfurt am Main: Suhrkamp, 1992, s. 277-336.

22 Socialer Konstruktivismus - eine neue Perspektive in der Psychologie. In SCHMIDT, Siegfried J. (ed.). Kognition und Gesellschaft. Der Diskurs des Radikalen Konstruktivismus II. Frankfurt am Main: Suhrkamp, 1992, s. 116-145.
}

dovedou $k$ zamýšleným cílům.. ${ }^{23}$ Kaščák na Kupffera navazuje a odůvodňuje tuto skutečnost „nevypočitatelností subjektivity“. ${ }^{24}$ Jak píše Lenzen, pouze metodicky „na míru ušitá“ individuální forma vyučování vede $k$ efektivnějším proměnám poznatkové báze takto vzdělávajících se jedinců. Pedagog v tomto prrípadě přebírá novou roli, jež nemá být hlavním zprostředkovatelem, informátorem daných faktů, ale aranžérem vhodných situací a podmínek, animátorem stimulujícím žáky k plnému a efektivnímu využívání nabízených cest k žákovu konstruování poznatků a „sebeorganizováni"“, ${ }^{25}$ cest, jak se učit, vyhledávat informace a pracovat s nimi. Mezi vhodné podmínky patří mimo jiné i nabídka různých typů didaktických materiálů a metodických postupů, „optimální diferencované a minimálně selektované učební prostředí", což v případě edukace v muzeích může být daleko lépe naplněno.

\section{Spisovatel Ernst Hemingway} ve svém díle Komu zvoní hrana napsal, že „člověk není ostrov sám pro sebe“. ${ }^{26}$ Obdobně píše Luigi Pirandello ,to, co považujeme za odvěce vnitřní, naše vědomí, není ničím jiným než ostatní $v$ nás “. ${ }^{27}$ Dostáváme se takto k druhé, dosud ne tak důkladně zpracované teorii sociálního konstruktivismu,

23 KUPFFER, Heinrich. Pädagogik der Postmoderne. Weinheim: Beltz, 1990, s. 14.

24 KAŠČÁK, Ondrej. Je pedagogika připravená na změny perspektiv? Rekontextualizace pohledů na výchovně-vzdělávací proces pod vlivem radikálního individuálního konstruktivismu a postmoderního sociálního konstruktivismu. Pedagogika, 2002, roč. 52, č. 4, s. 393.

25 PUPALA, Branislav a L'ubica OSUSKÁ. Vývoj, podoby a odkazy teorie konštruktivizmu. Pedagogická revue, 2002, roč. 52, č. 2, s. 101-114.

26 HEMINGWAY, Ernest. Komu zvoní hrana. Praha: Odeon, 2016.

27 KAŠČÁK, Ondrej. Je pedagogika připravená na změny perspektiv? Rekontextualizace pohledů na výchovně-vzdělávací proces pod vlivem radikálního individuálního konstruktivismu a postmoderního sociálního konstruktivismu. Pedagogika, 2002, roč. 52, č. 4, s. 397. 
která navázala na myšlenky individuálního konstruktivismu.

Determinujícími se staly zejména práce ruského psychologa Lva Semjonoviče Vygotského, amerického zakladatele sociálního učení Alberta Bandury a amerického představitele Jeromeho Brunera. Samotný pojem sociální konstruktivismus se však poprvé v odborné terminologii objevil u pracovní skupiny psychologické fakulty Bochumské univerzity $\mathrm{v}$ roce $1988 .{ }^{28} \mathrm{Na}$ rozdíl od individuálního konstruktivismu se ten sociální obrací od nitra jedince $\mathrm{k}$ dění ve společnosti. Svět je chápán jako sociální systém, který tvoří skupina jedinců, jež „si vytvořili a sdílejí srovnatelnou či shodnou konstrukci skutečnosti, přizpůsobili jí svou činnost a vzhledem k této konstrukci skutečnosti spolu interaguji“. ${ }^{29}$ Zatímco individuální konstruktivisté považují za klíčovou jedincovu konstrukci světa, autoři sociální teorie dávají naroveň konstrukci mnoha individuí. Proces poznávání, vnímání a myšlení nemusí být pouze individuálněpsychologickou záležitostí, nýbrž společensky determinovanou. ${ }^{30}$

V učení tak sehrává roli kulturní a sociální prostředí a interakce mezi jedinci. Nejedná se přitom o návrat $\mathrm{k}$ behavioristickému myšlení, jde spíše

o „epistemologický behaviorismus“, který spočívá v intersubjektivním poznávání světa, ${ }^{31}$ o sociální

29 ROTH, Wolff-Michael a Anita ROYCHOUDHURY. The Social Construction of Scientific Concepts or the Concept Map as Conscription Device and Tool for Social Thinking in High School Science. Science Education, 1992, roč. 76, č. 5, s. 531

30 KAŠČÁK, Ondrej. Je pedagogika připravená na změny perspektiv? Rekontextualizace pohledů na výchovně-vzdělávací proces pod vlivem radikálního individuálního konstruktivismu a postmoderního sociálního konstruktivismu. Pedagogika, 2002, roč. 52, č. 4, s. 397.

31 RORTY, Richard. Holizmus, interiorizmus a ambícia transcendencie. Filozofia, 1993, roč. 48, č. 4, s. 226-241.
}

systém, v němž si množství jedinců vytvořilo srovnatelnou či shodnou konstrukci skutečnosti, již sdílí a jíž se přizpůsobují. ${ }^{32}$ Jako se individuální konstrukce vytváří v lidském mozku, společná skupinová konstrukce skutečnosti vzniká v „komunálním jazykovém diskurzu“, upevňuje se opakovanými návyky a legitimuje narativním způsobem ve formě „tradic, zvyků, představ a mýtů o tom, jak něco je, či jak něco má být ${ }^{\text {“. }}{ }^{33}$ Souhrnně řečeno, sociální konstruktivisté nepovažují myšlenky za „čistě individuální pohledy na svět, ale odrážejí kulturně sdílený náhled na svět, konstituovaný specifickými jazykovými prvky a figurami“ ${ }^{34}$

Důležitou roli sehrává komunikace, socializace, enkulturace a vzájemné působení jedinců, vedoucí ke „společenské shodě v názorech na svět". Principy, podporující smysluplnou skupinovou formu učení v podobě vzájemné konfrontace a ovlivňování dětských pojetí, se pokusila vymezit A. L. Brownová. Jedná se o aktivní komunikaci a spolupráci, facilitaci a strategické řízení učební činnosti, pozitivní motivaci a prožívání kladných emocí při učení, diagnostiku jednotlivých rozdílů v distribuci znalostí a zájmů jedinců. ${ }^{35} \mathrm{Jak}$ píše Kaščák, na rozdíl od radikálního konstruktivismu, doporučujícího spíše individuální formu učení, v př́ípadě sociálně-

\footnotetext{
32 HEJL, Peter M. Die zwei Seiten der Eigengesetzlichkeit: Zur Konstruktion natürlicher Sozialsysteme und zum Problem ihrer Regelung. In SCHMIDT, Siegfried J. (ed.). Kognition und Gesellschaft. Der Diskurs des Radikalen Konstruktivismus II. Frankfurt am Main: Suhrkamp, 1992, s. 116-145.

33 KAŠČÁK, Ondrej. Je pedagogika připravená na změny perspektiv? Rekontextualizace pohledů na výchovně-vzdělávací proces pod vlivem radikálního individuálního konstruktivismu a postmoderního sociálního konstruktivismu. Pedagogika, 2002, roč. 52, č. 4, s. 401.

34 Tamtéž, s. 403.

35 BROWN, Ann L. The Advancement of Learning. Educational Researcher, 1994, roč. 23, č. 8, s. 4-12.
}

konstruktivistické výuky lze vnímat prvky řídicího systému, $\mathrm{v}$ němž sehrává roli i pedagog, „socializovaný do způsobů, jak svět konstruuje většina“. Učitelé a muzejní pedagogové zejména mají být „jakýmsi ochráncem tradic a sociálního konsenzu, protože ty jsou z globálního hlediska pro život společenství nejdůležitějšǐ “. ${ }^{36}$

Na konci velmi stručného nástinu konstruktivistické teorie poznávání a učení se pokusme slovy jejich badatelů shrnout hlavní myšlenky, které jsou klíčové pro konstruktivistické didaktické přistupy, jednoznačně orientované $\mathrm{k}$ žákovi a jeho způsobům myšlení. Tím nejzásadnějším, čím je konstruktivismus pro didaktiku, je sdělení, že „žádná vzdělávací činnost nemůže obejít dosavadní poznatky učících se, je třeba s nimi počítat““ ${ }^{37}$ Obdobně, jako je „vědecké poznání poznáním konstruovaným, vynalezeným, vyjednaným a argumentovaným “, ${ }^{38}$ vychází i žákovo poznání ze zkušeností pozorováním, zkoumáním, ověřováním a strukturováním nových jevů poznávaného světa. Úkolem vyučujícího by proto mělo být předkládat takové podmínky učení, které žákovi umožní „pozorovat, experimentovat, zjištovat a vyhledávat fakta, na jejich základě formulovat hypotézy, ty potom ověrovat, verifikovat nebo falzifikovat, hledat uplatnění poznatků $v$ praktickém životě, tedy učit se získávat, tř́dit a kriticky hodnotit informace a jejich zdroje“. ${ }^{39}$ Rysem individuálního konstruktivistického př́stupu,

\footnotetext{
36 KAŠČÁK, Ondrej. Je pedagogika připravená na změny perspektiv? Rekontextualizace pohledů na výchovně-vzdělávací proces pod vlivem radikálního individuálního konstruktivismu a postmoderního sociálního konstruktivismu. Pedagogika, 2002, roč. 52, č. 4, s. 405.

37 BERTRAND, Yves. Soudobé teorie vzdělávání. Praha: Portál, 1998.

38 Tamtéž.

39 ŠKODA, Jiří a Pavel DOULÍK. Psychodidaktika: metody efektivního a smysluplného učení a vyučování. Praha: Grada, 2011.
} 
který je logicky aplikovatelný na individuální formu vyučování, by pak mělo být vytvoření „diferencovaného a minimálně selektovaného učebního prostredí, poskytující nejlepší předpoklady pro učení. ${ }^{40}$

\section{Konstruktivistické muzeum}

Nastíněné teze konstruktivistické teorie učení, která do popředí učebního procesu staví vzdělávajícího se jedince - žáka a klade důraz na rozvoj jeho osobnosti, začínají být postupně aplikovány jak ve formálním tak informálním vzdělávání. Své místo nachází rovněž ve výstavní a prezentační didaktice, zejména ve specifických edukačních programech muzeí. ${ }^{41}$ Přestože, jak tvrdí George Hein, dosud neexistuje čistě konstruktivistické muzeum, lze $\mathrm{v}$ řadě $\mathrm{z}$ nich spatřovat více či méně prvků konstruktivistický přístup učení podporujících. Položme si nyní otázku, jak by mělo vypadat muzeum, jež by dle Heinova diagramu odpovídalo zásadám konstruktivismu. ${ }^{42}$

Adjektivum „konstruktivistické“ Hein připisuje takovému muzeu, $\mathrm{v}$ němž návštěvníci či žáci a studenti konstruují poznatky $\mathrm{z}$ exponátu samostatně nebo společně $s$ jinými lidmi a proces získávání poznatků z exponátu je konstruktivistickou aktivitou. ${ }^{43}$ Jak tomu porozumět? K objasnění

40 KAŠČÁK, Ondrej. Je pedagogika připravená na změny perspektiv? Rekontextualizace pohledů na výchovně-vzdělávací proces pod vlivem radikálního individuálního konstruktivismu a postmoderního sociálního konstruktivismu. Pedagogika, 2002, roč. 52, č. 4, s. 388-414.

41 Srov. KOLAŘíKOVÁ, Veronika.

Konstruktivistické teorie učení a jejich využití v edukační realitě muzea. Pedagogická orientace, 2018, roč. 28 , č. 3 , s. 496-540.

42 Srov. MIKULÁŠKOVÁ, Monika. Proměny konstruktivismu v muzejní pedagogice George E. Heina. Museologica Brunensia, 2017, roč. 6, č. 1, s. $41-47$.

43 HEIN, George E. The constructivist museum. In HOOPER-GREENHILL, Eilean. The Educational Role of the Museum. London, New York: Routledge, 1994, s. 76-77.
Hein používá konfrontaci s charakteristikou diametrálně odlišného systematického muzea, odpovídající teorii transmisivní, jehož náplní je vystavování předmětů $\mathrm{v}$ jejich dokonalosti a logické struktuře (chronologické, genealogické, ontogenetické aj.) a proces učení $\mathrm{v}$ něm probíhá jednoduchým (výkladovým) způsobem. ${ }^{44}$

Systematické a konstruktivistické muzeum vedle sebe existují jako dva protipóly. V prvním je návštěvník jen pasivním př́ijemcem hotových, podle určitého řádu předem strukturovaných informací o „vitrínovaném“ exponátu, předkládaných jedinou cestou pomocí výkladu průvodce nebo $\mathrm{v}$ textu informačních tabulí. Naopak v konstruktivistickém muzeu jedincům nejsou předkládána dokonalá ucelená fakta, návštěvník je spíše motivačním způsobem stimulován $\mathrm{k}$ tomu, aby sám nebo s druhými zkoumal, pátral a objevoval potřebné informace z objektů, doprovodných médií či inscenovaného prostoru skrze vlastní aktivitu a přitom rozvíjel své schopnosti, dovednosti a myšlení. Prostřednictvím rozmanitých cest interakce $s$ předměty, podněcujícími myšlenkovou aktivitu, si tak vytvářel vlastní strukturu poznávaného. Důležitá je přitom vnitřní motivace, sloužící jako „pohon“ v učebním procesu. ${ }^{45}$

Z uvedeného tedy vyplývá, že $\mathrm{v}$ tak zvaném konstruktivistickém muzeu je stěžejní vytvoření co nejideálnějších, různé skupiny návštěvníků a typy učebních strategií zohledňujících podmínek učebního procesu, čímž takovému muzeu v praxi vyvstává v oblasti jeho prezentační (a edukační) funkce primární úkol - nikoliv zprostředkovávat fakta př́imo, ale

\section{Tamtéž. \\ 45 Tamtéž.}

zvažovat a volit ty nejvhodnější strategie inscenace objektů a implementace doprovodných didaktických prostředků, které motivují, stimulují a facilitují učební proces. V žádném případě nejde o výstavu „pouhých“ herních prvků, jak je tomu v některých science centrech, které by bez objasnění vědeckých principů a konkretizace učebních úloh mohly klesnout na úroveň zábavy. Také se nejedná o stanoviště digitálních kiosků s edukačními aplikacemi, jež by sice měly vzdělávací charakter, avšak zcela upozadily vnímání originálních artefaktů, která činí muzea muzei.

Dnes stále více podporované digitální technologie, ale i další didaktická média, at̉ už se jedná o audiovizuální záznamy, zvukové a světelné animační efekty, komiksové postavy, či tradičnější pomůcky jako pracovní listy, muzejní kufř́ík, rellay mají sloužit jako podpůrné, podněcující a motivační prostředky, směrující pozornost, smyslovou percepci i myšlenkové procesy $k$ muzejní podstatě - exponátům a jejich jádrovému obsahu v kontextu historickém, současném i budoucím.

Jmenované prvky by tedy současně měly vybízet $\mathrm{k}$ nahlížení na objekty a sledované téma $\mathrm{z}$ různých perspektiv, přičemž volba té které perspektivy bude záležet na návštěvníkovi samotném. To znamená, že by si návštěvník mohl vybrat, zda chce na sebe nechat působit auru objektu či scenérie a soustředit se na smyslové podněty nebo se dozvědět o předmětech a inscenovaném tématu více. ${ }^{46}$

Důležitou roli sehrává již samotný výběr muzeálií, které mají být v expozici prezentovány. Oproti systematickému muzeu, které většinou zprostředkovává téma $\mathrm{z}$ jednoho úhlu pohledu, mělo by

46 Tamtéž. 
konstruktivistické muzeum volit strategii srovnávání, postavit vedle sebe objekty z různých sociálních, kulturních, geografických i jiných oblastí a tak podpořit kritické myšlení, příležitost ke sdělení vlastních názorů a postojů.

V neposlední řadě pak podpořit tvůrčí nápady a činnost jedinců, které by mohly být zahrnuty do zvláštního prostoru muzea, jež by sloužil jako zpětná vazba a podnět k diskuzím.

Jedním z parametrů muzejní scénografie je směr prohlídky. V konstruktivistickém muzeu nemá mít výstava dle Heina počáteční ani konečný bod. ${ }^{47}$ Návštěvníci mohou dle vlastní motivace, preferencí, zájmu a znalostí volit pořadí a míru pozornosti jednotlivým exponátům. To ovšem neznamená, že by zůstali zcela bez průvodcovské či pedagogické opory. Jednou z možností způsobu facilitace ve vzdělávání se v muzeu mohou být nepersonální typy průvodců v podobě audiovizuální (obrazovky, kiosky, mp3 přehrávače), textové (pracovní listy, orientační plánky), obrazové (například komiksové postavy) nebo kombinované (muzejní kufř́ík).

\section{Konstruktivistické přístupy v muzejním edukačním programu}

Má-li být muzeum postaveno na teorii konstruktivismu, měly by se popsané aspekty prolínat rovněž koncepcemi nabízených edukačních programů pro vytyčené cílové skupiny. Hovoříme-li o výchovněvzdělávacích programech pro školní skupiny, jedná se o proces záměrné edukace, z čehož logicky vyplývá, že zvláště zde nelze nechat jedince ve vlastním světě konstruování, nebot' by mohlo dojít k vytvoření miskonceptů. Proto lze v oblasti prezentační didaktiky, do níž edukační programy řadíme, logicky předpokládat aplikovatelnost jen některých aspektů konstruktivistického muzea. Možnost volby směru, preference ve výběru exponátů či perspektivy zaměstnávání se vystaveným v programech nehrají takovou roli, naopak větší prostor je věnován prekonceptům žáků, pedagogickým profilům, strukturaci poznatků a závěrečné zpětnovazební diskuzi. Velmi častá je také forma skupinové práce, podporující formování sociálních i osobnostních kompetencí. Samostatná činnost je motivována podpůrnými výukovými metodami jako je hraní rolí, hands-on, objektové učení a rukodělné či jiné psychomotorické aktivity. ${ }^{48}$

Podle Phillipsovy kategorizace by žák v konstruktivistické výuce měl zaujmout tři základní role: aktivní (získávat poznatky aktivním způsobem, nebýt pasivním př́ijemcem), společenskou (poznatky vytvářet $\mathrm{v}$ dialogu s ostatními, nejen individuálně) a kreativní (rekonstruovat jeho původní představy $\mathrm{v}$ interakci s ostatními). ${ }^{49}$

$\mathrm{V}$ neposlední řadě je nutné si uvědomit, že při pluralitě vědeckých teorií o vzdělávání by zároveň nebylo správné, aby koncepce edukačního programu striktně stavěla na principech jedné teorie a nezohledňovala $\mathrm{v}$ určitých oblastech efektivnější a vhodnější zásady teorií jiných, včetně transmisivní. Na tuto skutečnost odkazuje F. Kuřrina v souvislosti s realistickým konstruktivismem: „Konstruktivní vyučování tedy může obsahovat transmisi celých partií, může obsahovat $i$ instrukce $k$ řešení typických úloh." A jak dále uvádí: „Ne všechno se dá vymyslet. Jsou informace, které je nutno získat

\footnotetext{
48 ŠIMÍK, Ondřej. Utváření obsahu př́rodovědné výuky na 1. stupni ZŠ v konstruktivistickém pojetí - výzkum tematického celku VODA. Ostrava: Ostravská univerzita v Ostravě, 2012.

49 Tamtéž.
}

z učebnice, dalš́ literatury, internetu apod., avšak hlubši poznání by mělo probíhat $v$ žákově mysli jeho vlastní konstrukci.“"50

\section{Příklady aplikace konstruktivistického př́istupu v muzejní edukaci}

Pro ilustraci aplikace konstruktivistických přistupů do muzejní edukace byly vybrány dva edukační programy, realizované v průmyslových muzeích textilní továrny $\mathrm{v}$ Bocholtu a továrny na zpracování zinku v Oberhausenu, $\mathrm{v}$ nichž autorka realizovala $\mathrm{v}$ roce 2017 kvalitativní výzkumná šetření, jejichž záměrem bylo zmapovat didaktické přístupy ve školních edukačních programech vybraných muzeí. Výzkum probíhal formou hospitací a rozhovorů s muzejními lektory, dokumentací expozic, pořizováním záznamů edukačních programů a studiem tištěných dokumentů (manuály pro lektory či učitele, katalogy, pracovní listy, tišstěný průvodce expozicí). Hospitované edukační programy $\mathrm{v}$ obou zmíněných průmyslových muzeích byly koncipovány jako kombinace skupinové práce s pracovními listy na principech individuální a sociální konstruktivistické teorie učení. Cílem příspěvku není seznámit čtenáře s procesem samotného výzkumu, ale deskriptivně analytickým způsobem přiblížit aplikaci konstruktivismu v muzejní praxi.

Obě zmíněné kulturní památky Textilwerk Bocholt a Zinkfabrik Altenberk jsou řazeny mezi tzv. nová průmyslová muzea, která byla zakládána od 60 . let 20. století ve Spolkové republice Německo $\mathrm{v}$ prostorách bývalých průmyslových závodů jako byly doly, hutě, textilní a jiné továrny.

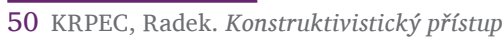
k výuce kombinatoriky. Ostrava: Ostravská univerzita v Ostravě, 2016.
} 
Pro všechna takto označovaná muzea je společná autenticita prostředí v podobě zachovalých budov, ale i vnitřního vybavení, dále pak prezentační koncepce zaměřující se na dějiny každodennosti, kdy se do popředí dostává člověk, nikoliv stroj a v neposlední řadě intence edukační a s ní související široká nabídka výchovně-vzdělávacích programů a akcí pro různé skupiny návštěvníků a školních skupin. ${ }^{51}$

\section{Textilwerk Bocholt}

V 60. letech 20. století docházelo $\mathrm{k}$ výrazným změnám $\mathrm{v}$ oblasti Nordhein Westfalen, spojeným s ukončením provozu řady továren. Stále více průmyslových podniků bylo zavíráno a následně likvidováno. Členové spolku Westfalen Lippe se rozhodli průmyslové objekty i s jejich vybavením zachovat. Po schválení ministerským předsedou Heinzem Kühnem byla zahájena sanace řady bývalých továrních areálů a mnohé z nich zpřístupněny veřejnosti jako muzeum. Pod hlavičku LWL Industriemuseum přešlo celkem osm technickoprůmyslových památek, včetně bývalé textilní továrny $\mathrm{v}$ Bocholtu. ${ }^{52}$

Díky zachovalému stavu téměř celého areálu byla prezentace textilní výroby situována do tří původních budov: přádelny, tkalcovny a tkalcovského domu se zahradou. Čtyři patra impozantní budovy bývalé přádelny vnáší pohled do historické i moderní

51 STEINERT, Arne. Konzepte der Musealisierung von Technik und Arbeit. In VOGT, Arnold a Hans-Ulrich NIEMITZ (eds.). Technik - Faszination und Bildung. Impulse zur Museumspraxis, Didaktik und Museologie. München: Verlag Dr. Christian Müller-Straten, 2008.

52 PARENT, Thomas. Das Westfälisches

Industriemuseum Dortmund - Anmerkungen zu den Chancen und Problemen der

Musealisierung von Industriedenkmälern. In VOGT, Arnold a Hans-Ulrich NIEMITZ (eds.) Technik - Faszination und Bildung. Impulse zur Museumspraxis, Didaktik und Museologie. München: Verlag Dr. Christian Müller-Straten, 2008. techniky, módního designu a textilního umění expozice. Prezentační koncepce blízké tkalcovny spočívá v navození pracovní atmosféry doby skrze třicet funkčních stavů s původní řemenovou transmisí, originálním vybavením, s důrazem na přiblížení každodenní práce lidí (topičů, strojníků, mechaniků, tkalců, mistrů, úředníků a majitele továrny). Kompletně zařízený dělnický dům se zahradou, osazenou původními plodinami a dvorkem pro domácí zvířata, poskytuje vhled do každodenního života tkalcovské rodiny. ${ }^{53}$

\section{Edukační program „Wilhelmův pracovní den“"}

Rozsáhlý edukační potenciál muzea je plně využíván nejen v samotných expozicích, ale také ve výchovněvzdělávacích programech, $\mathrm{z}$ nichž následující vychází z popisovaných zásad konstruktivismu a svou koncepcí ve značné míře podporuje naplňování a rozvíjení tří základních rolí žáků, tak jak jsou definovány Phillipsem. Program s názvem „Wilhelmův pracovní den“ je určen žákům šestých až devátých tříd a je založen na individuálním získávání poznatků a vytváření vlastních úsudků aktivní formou ve skupinové práci. Pomocí metody hraní v roli, úkoli̊ v pracovních listech, skupinového dialogu a závěrečné diskuze žáci získávají, třídí a (re)konstruují poznatky, jimiž odkrývají dějiny každodennosti rodin tkalců na přelomu 19. a 20. století na příkladu mladého továrního tkalce Wilhelma. ${ }^{54}$

\footnotetext{
53 KUHN, Anja. Käpt'n Henri und Co. Von Schrittmachern und Stolpersteinen der Museumspädagogik im Westfälischen Industriemuseum. Standbein Spielbein. Museumspädagogik aktuell, 2002, sv. 62, s. 25. 54 Informace vychází z hospitace na programu a rozhovoru s muzejními pedagogy muzea, realizované v rámci autorčina výzkumu v červnu 2017 (pozn. aut.)
}

Úvodní část programu je věnována zjištování prekonceptů - představ žáků o práci v textilní továrně a životě tkalcovské rodiny. Rozděleni do čtyř tematických skupin jsou následně žáci vysláni na určitá místa expozice. Vlastní činnosti žáků sehrávají ústřední roli v objevovacím procesu poznávání. Osvojování poznatků zde probíhá na principu kognitivní, psychomotorické i afektivní domény za použití metod slovních, názorně-demonstračních i praktických. V konfrontaci s hmotnými, písemnými, vizuálními i auditivními prameny jsou žáci v aktivizační části pracovních listů vedeni k třídění, analýze, organizování a propojování získaných informací. V závěru jsou pod vedením muzejního pedagoga skupinami sdíleny rekonstruované poznatky a prezentovány vlastní úsudky o každodennosti ve sledované době.

\section{Pracovní listy „Co má společného člunek $s$ Wilhelmovým pracovním dnem" 55}

Ve snaze detailnějšího přiblížení konkrétní podoby konstruktivisticky koncipovaných pracovních listů byl pro představu vybrán jeden ze čtyř avizovaných.

Téma: Wilhelmův pracovní den, pracovní místo, tkalcovský stav.

Úkol: Vžít se do role tkalcovského chlapce Wilhelma a poznat jeho pracovní den se zaměřením na pracovní podmínky, zdraví a bezpečnost práce.

Dílčí témata jádrového obsahu:

- Role člunku v práci na tkalcovském stavu.

- Poškození sluchu hlukem.

55 Pracovní listy SCHÜRENKAMP, H. J. Wilhelms Arbeitstag in der Fabrik. Arbeitsplatz Webstuhl. LWL Industriemuseum, Textilmuseum in Bocholt, 2003. [nepublikováno]. (pozn. aut.) 
- Postoj při práci.

- Prach.

- Nebezpečí úrazu letícím člunkem.

- Nebezpečí pádu a zranění při styku s hřídelí.

- Nebezpečí úrazu z nepozornosti.

V počáteční motivační fázi je použito hned několik didakticky rozmanitých incentiv, vyznačujících se metodickou vzestupnou dynamičností, obsahovou a smyslovou provázaností. Zájem o učení se formou objevování a hraní v roli má stimulovat již úvodní otázka „Co má Wilhelm společného s člunkem?" a s ní související zadání „Vyhledejte člunek - předmět, znázorněný na fotografii - v bývalé tkalcovské hale“. Počáteční percepce je směřována od zobrazeného (fotografii) ke skutečnému (předmět).

Proces poznávání je zahájen induktivním přístupem - od smyslové zkušenosti k jazyku. Studenti jsou vedeni k odkrývání a pojmovému uchopení vlastností, účelu a významu člunku vlastní myšlenkovou činností na základě smyslového učení. Kromě prohlížení samotného člunku a jeho umístění v tkalcovském stavu mají příležitost zažít stav v provozu a současně vnímat hluk běžících strojů a pozorovat pohyby člunku i jiných součástí stavu. V duchu známého rčení „Slyším a zapomínám. Vidím a pamatuji si. Dělám a rozumím!"56 zakončuje fázi evokace zážitková rukodělná aktivita, při níž si studenti sami vyzkouší proplétání vláken člunkem na ručním dřevěném stavu. Veškeré poznatky, získané zcela vlastním konstruktivistickým zpo̊sobem, následně shrnou v pracovním listě

56 PETTY, Geoffrey. Moderní vyučování. Praha: Portál, 2008. odpověd’mi na otázky „K čemu a jak slouží člunek?", „Kde se v expozici nachází?“, „Jak souvisí s prací Wilhelma?".

Po strukturaci počátečních poznatků o funkci člunku a tkalcovském stavu je pozornost soustředěna na negativní faktory pracovních podmínek. Každý z nich je zkoumán z několika perspektiv, sledujících různé typy učení, metod i pramenů. První $\mathrm{z}$ faktorů, $\mathrm{k}$ němuž se vztahují úlohy objevování na senzorické i racionální bázi, je nadměrný hluk strojů, s nímž byli studenti konfrontováni v úvodu. Při opětovném uvedení tkalcovských strojů do pohybu se dle zadání mění vjemová figura, cílem je detekovat mechanismus, který je př́ičinou největšího hluku. Informativní část v pracovním listu $\mathrm{k}$ této problematice následně poskytuje základní fakta

o neuvěřitelném počtu až jednoho tisíce stavů v hale, které byly $\mathrm{v}$ bocholtské tkalcovně současně v chodu a hřmot, který vydávaly, byl v tehdejší době srovnatelný s hlukem dnešního tryskového letadla. S podporou rozvíjení schopnosti vlastní úvahy cílí další úkol na to, zamyslet se, proč hluk ohrožoval tkalce na přelomu století mnohem více než například ke konci 20. století a měl za následek úplnou hluchotu zejména starších pracovníků. Jakousi nápovědou je fotografie z cca druhé poloviny 20. století, zobrazující staršího tkalce se sluchátky na uších.

Příčiny zdravotních problémů při tkalcovské práci nebyly pouze ve vnějších podmínkách. Mnozí z tkalců trpěli potížemi s obratlovou ploténkou a páteří. Proč tomu tak bylo, mají studenti vysvětlit po „malém experimentu“. Na dobu tří minut musí zaujmout postoj tkalce při obsluze stavu: předklonit se a předpažit ruce. Odpověd' je o to snazší, když si představí, že pracovní doba okolo roku 1900 byla v průměru 11 hodin denně.

Převážně smyslové

a senzomotorické učení střídá práce s písemnými dobovými prameny, rozvíjející kritické myšlení, schopnost dedukce, komparace, analýzy i interpretace textu. Cílem je porozumět textu, objevit smysl sdělení, interpretovat hlavní myšlenku vlastními slovy a elaborovat její vztah s dosavadními poznatky a s reálným autentickým prostředím. Krátké, avšak informačně bohaté úryvky z dochovaných svědectví, v tkalcovně pracujících mužů i žen, podněcují k zamyšlení nad prríčinami onemocnění dýchacích cest a původu prašnosti.

Jinde zase nad důvody, které i přes zákaz vedly pracovníky k podstupování rizika „slisování rukou“ při opravování kazů na tkanině v průběhu chodu strojů, které mohlo mít za následek dočasnou nebo trvalou pracovní neschopnost. Rozmanitost textu z hlediska autorství a slohu pomáhá nahlížet na situaci z několika úhlů pohledu. Vedle svědectví samotných dělníků stojí úřední zpráva, posudek mistra či dopis továrníka. Jeden z prríkladů konfrontující realitu je úřední odůvodnění nedůležitosti legislativního opatření ve věci ochrany dělníků při práci jistým bocholtským úředníkem Degenerem z 6. října 1873, který přisuzoval většinu pracovních úrazů a nehod nezodpovědnosti dělníků. Na jiném místě $v$ pracovním listu se naopak studenti dočtou, že ještě ve čtyřicátých letech 20. století bylo zaznamenáno za tříleté období 1087 nehod zapříčiněných odlétávajícím člunkem. Texty nejsou s ohledem na tematické podoblasti řazeny v návaznosti, což není na škodu, nebot je zde ponechán prostor pro rekonstruování původních názorů a úvah, navrácení se 
k předchozím otázkám a tématům, propojování jednotlivých poznatků a tím rozvíjení již zmiňovaného kritického myšlení.

Zadání k výňatkům z písemných pramenů jsou prokládány úkoly k interpretaci textověobrazových médií - plakátů a cedule. Právě problematika nebezpečí odlétávajícího člunku je příznačným způsobem reflektována na kopii plakátu, jehož originál mají studenti vyhledat v hale. Jeho obsahem je kresba, zobrazující muže, uhýbajícího právě letícímu člunku ze stavu, stojícího jen cca půl metru od tkalce. Obraz je doplněn sloganem „Tkalci, udržujte svůj lapač člunku v pořádku. Chraňte sebe i své kamarády!". Pomocí návodných otázek je provedena obsahová analýza „Co se stalo na obrázku?", „Co činilo práci tak nebezpečnou?". Obrazová scénická názornost vede $\mathrm{k}$ uvědomění si problému, který má být následně detailně zkoumán již u hmotného pramene - originálního stavu s cílem zjištění a objasnění řešení. Od symbolického zobrazení přes pozměněné realistické se tak na kuželu zkušeností směřuje k prrímému styku s objektivní realitou. Tato deduktivní cesta učení je zároveň problémovým učením. Vyobrazená situace přímo stimuluje k otázkám: „Jak k tomu mohlo vůbec docházet, aby člunek vyletěl z koleje?“, „Dalo se tomu nějak zabránit?“, „Jakým způsobem by se dala zajistit bezpečnost tkalců při práci?". Na posledně zmíněné nachází studenti odpověd’ jak v expozici, tak na fotografii se stavy s postranními sítěmi, přes které člunek neproletěl.

Metodická rozmanitost, zohledňující strategie učení studentů, je spatřována u předposledního, zde ještě nezmíněného problematického faktoru, jímž byla údržba či uklízecí práce v blízkosti rotujících součástí. Nebezpečí při pádu a následné zranění stykem s hřídelí opět znázorňuje plakát, který měl mít ve své době edukativní a preventivní charakter. Je na něm vyobrazen muž, leštící okna, jednou nohou stojící na žebříku, jemuž hřídel trhá zachycenou košili.

Váže se $\mathrm{k}$ němu několik úkolů: „Popište znázorněnou situaci“, „Jak by muselo znit bezpečnostní nařizení, které by předešlo této nehodě?", „Změř chodbu mezi řadou strojü“, „Uved', proč by majitel továrny odmítl návrh umístění strojů ve větší vzdálenosti od sebe“. Zadání jednoznačně přispívají $\mathrm{k}$ podpoře složitých a produktivních myšlenkových operací. Opět jako u předchozí situace studenti řeší konkrétní problém, jehož součástí je senzomotorická aktivita $\mathrm{v}$ podobě měření šířky chodby. Na vyšší kognitivní úrovni jsou druhý a třetí úkol, vyžadující tvưrčí myšlení a schopnost logického uvažování.

Na stejném principu spočívají také poslední dvě zadání, doplněná fotografií počítadel pohybů člunku, jejichž instalace v továrně svým způsobem vysvětluje původ některých zde nastíněných a studenty objevovaných nebezpečí. Každé odstavení stavu pro tkalce ve výsledku mělo za následek nižší mzdu. Proč byla počítadla na stavy připevněna a jak souvisela $s$ výší platu, je definitivně posledním úkolem konstruktivistické a současně pátrací cesty za poznáním jednoho ze čtyř jádrových obsahů edukace v dochované textilní továrně v Bocholtu.

Pracovní listy „Wilhelmův pracovní den v továrně“ jsou na první pohled textově obsáhlé. Díky dobré proporci informačního textu s aktivizujícími úkoly, vhodně vybraným vizuáliím a ukázkám z dobových písemných pramenů i celkové koncepci tematicky sledující každodenní život spjatý s konkrétní postavou tkalcovského chlapce Wilhelma, textová obsáhlost netrpí přehlceností.
Pracovní listy v edukačním programu zastupují úlohu pedagoga, plní roli průvodce tématem, orientují v prostředí, koncentrují pozornost a percepci návštěvníků na konkrétní vjemové figury a rozvíjí myšlenkové operace. Také podporují různé strategie a postupy učení i práce s odlišnými typy médií, pomáhají strukturaci poznatku, nahlížení na problém z různých úhlů pohledu, formování vlastních úsudků a jejich kritického zhodnocení.

Metoda „objevování“ a „hands-on“ je umocněna vžitím se do role konkrétní reálné historické postavy přibližně stejné věkové kategorie jako sami studenti. Tím je dosažen předpoklad pro vytvoření vnitřních motivů dozvědět se o podmínkách, v jakých pracovali jejich vrstevníci v minulosti, nebo ve kterých by museli pracovat oni sami jako potomci tkalců na přelomu 19. a 20. století.

\section{Zinkfabrik Oberhausen}

Na principu tzv. nových průmyslových muzeí byla zpřístupněna také skupina šesti dochovaných technickoprůmyslových objektů v oblasti německého Porýní. Centrální památkou a hlavním střediskem tzv. LVR Industriemuseum, kde je situována správa s ředitelstvím, knihovnou, fotoarchivem a dílnami, se stala bývalá továrna na zpracování zinku a Svatoantonínská hut' v Oberhausenu. Za účelem přiblížení dějin těžkého průmyslu interaktivní formou mladé generaci zde byly muzejně-pedagogickým týmem vytvořeny nové edukační programy, zohledňující rámcové vzdělávací programy na školách.

Tematicky navazují na učivo nazvané „Průmyslová revoluce“, které je vyučováno na německých školách v rámci výukového bloku „Evropa se proměňuje“. Metodicko- 
didaktická struktura jednoho z programů, který byl vybrán jako druhý z ilustrativních př́kladi̊ konstruktivistického učení v muzeu, je v mnohém analogická $\mathrm{s}$ výše popsanou lekcí v Bocholtu. Průvodcem objektového učení jsou i zde pracovní listy se shodným motivačním prvkem metody role plays, organizační formou je skupinová výuka realizovaná v sedmi menších skupinách. Cílem každé skupiny je v roli konkrétní postavy, která $\mathrm{v}$ roce 1900 pracovala v továrně nebo ji navštívila, získat pomocí úkolů co nejvíce informací o tehdejších pracovních podmínkách, srovnat je se současností, formulovat vlastní úsudek o továrně ve vztahu k člověku nebo životnímu prostředí a své poznatky a názory prezentovat ostatním. ${ }^{57}$

\section{Pracovní listy „Objevování dějin průmyslu“}

Pracovní listy s názvem „Objevování dějin průmyslu“ mají na první pohled relativně jednoduchou strukturu, již tvoří úvodní pasáž, osm úkolů a stručný odkaz k místu závěrečné prezentace. Úvodní větou „V̌̌ijte se do role.... S pomocí pracovních listů si vytvorte úsudek o továrně a nakonec predstavte vašim spolužákům, co jste zažili $v$ roli ..." ${ }^{58}$ jsou žáci motivováni k poznávání aspektů tovární výroby a každodennosti formou vcítění se do situace některé ze sedmi postav:

- turisty;

- špiona, jehož cílem je získat informace o nejnovější technice výroby železa a oceli;

- předáka Heinricha Mankowského, jehož náplní

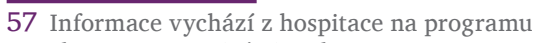
a rozhovoru s muzejními pedagogy muzea, realizované $\mathrm{v}$ rámci autorčina výzkumu v červnu 2017 (pozn. aut.).

58 Volně přeloženo z němčiny (pozn. překl.). práce bylo rozdělování

a organizování práce dělníkům

a kontrolování provozu v chodu;

- dělníka, u něhož má školní skupina za cíl posoudit, zda jeho práce byla vysněnou a dobře placenou nebo připomínala otroctví;

- pomocného dělníka;

- zdravotního úředníka, jehož záměrem je zhodnotit pracovní podmínky a následky tovární výroby pro přírodu;

- chemika, který má odhalit důsledky továrního provozu na ovzduší.

Smyslem aktivizující části je prostřednictvím návodných otázek a úkolů podněcovat $\mathrm{k}$ interakci s vystaveným se záměrem stimulace myšlenkových operací, formování dovedností zpracovávat sdělení různých typů pramenů i sekundárních médií a s tím úzce souvisejícího rozvíjení metakognitivních schopností. Oproti komplexní informačněaktivizační podobě pracovních listů, poskytujících jisté penzum faktografie, napomáhající $\mathrm{k}$ ukotvení a strukturaci postupně odkrývaných poznatků, jak tomu bylo u programu bocholtského textilního muzea, vystupují tyto pracovní listy spíše $v$ pozici mostu k pramenům - dochovaným reáliím a nositelům kulturně-historického vědomí. Série osmi učebních úloh slouží jednak jako návod pro studenty, na jaké objekty, vizuálie, audiovizuálie či ukázky písemných pramenů mají $\mathrm{v}$ expozici zaměřit svou pozornost a především, jak z nich získat potřebné informace, tyto analyzovat a nakonec $\mathrm{v}$ závěrečné prezentaci a diskuzi s ostatními skupinami interpretovat.

Kromě otázek, vyžadujících jednoduché myšlenkové operace, jsou studenti vedeni $\mathrm{k}$ složitějšímu a produktivnímu myšlení. Pro představu uved'me některé $\mathrm{z}$ vybraných skupin.

1) Úlohy předpokládající jednoduché myšlenkové operace: ${ }^{59}$

- „Vyhledejte $v$ blízkosti vysoké pece informace o podmínkách pracujících $v$ kasárnách a popište je."

- „Na velkém obraze jsou znázorněny různé výrobky firmy Krupp, napiš alespoň tři z nich.“"

- „Alex Mentz, 42 let, měl 1. 10. 1886 v 9:30 pracovní úraz. Jedná se o typický (častý) úraz $v$ té době? Odpověd' nalezneš $v$ knize."

2) Úlohy předpokládající složité myšlenkové operace:

- „Jděte k lokomotivě na konci ulice. Interpretujte význam železnice pro industrializaci."

- „Podívejte se na film o parním hamru. Za jakých podmínek si asi vydělal kovár nejvíce peněz?"

- „Pracující v kovárně se dorozumivali znakovou řečí. Jaké mohla mít práce v kovárně zdravotní následky?"

- „O čem vypovídá skleněné oko ve vitrínè?"

3) Úlohy předpokládající tvořivé myšlenkové operace:

- „Před promítačkou filmu se nachází vitrína, která ukazuje následky práce na zdraví lidí. Porovnejte je s vašimi zkušenostmi z praxe nebo z práce vašich rodičü."

59 Volně přeloženo z němčiny (pozn. překl.). 
- „Ve vitríně vedle muzejního bufetu se nachází zkušební zařízení ke snímání škodlivin továrního kouře. Zaujměte pozici ochránce přirodního prostredí a vyvod'te dopady škodlivin na něj.“

- „Byla by ještě dnes továrna, která tak škodí lidem, schválena $k$ provozu?"

- „Diskutujte o vývoji práce za poslední století. Změnily se nějak pracovní podmínky?"

Z obsahu zadání vyplývá, že smyslem učebního procesu není pouze zjištování a reprodukce fakt. Dưraz je kladen na aktivní (dnes spíše preferované slovo „kritické“) myšlení, zvažování důsledků přesahujících sledovanou historickou epochu, hledání souvislostí minulých jevů se současností. Rozmanitost lze spatřovat také $\mathrm{v}$ tématech. Odkaz na exponáty jako hamr, soustruh, trhací stroj, válec na válcování zinkových plechů a převodové soustrojí či model vysoké pece vede ke zkoumání technického vývoje a pokroku, naopak drobnější předměty jako skleněné oko a maska, videozáznam $s$ autentickými záběry konkrétních činností v továrně reflektují pracovní podmínky dělníků. Velkoformátové obrazy, znázorňující všední ruch ve městě, tovární provoz, dopravu a okolní krajinu, ale i přístroje na odhalení škodlivých látek v ovzduší či půdě předkládají otázku dopadu produktů průmyslové revoluce na životní prostředí.

Interakce s rozmanitými druhy médií jistě podporuje rozvíjení schopnosti vnímat věci kolem sebe a nahlížet na ně jako na nosné zdroje informací, jimiž nemusí být pouze přímá sdělení verbálního charakteru, rovněž jako na jejich hodnotu a míru názornosti. $\mathrm{V}$ případě hmotných artefaktů pak jde o budování vztahu ke kulturně-historickému dědictví, fascinaci objekty, kritický přístup $\mathrm{k}$ výtvorům lidské práce.

\section{Závěr}

Aplikace principů teorií (radikálního) individuálního a (postmoderního) sociálního konstruktivismu v muzejní edukaci má potenciál vést vzdělávající se jedince $\mathrm{k}$ smysluplnému, efektivnímu a zážitkovému učení $\mathrm{v}$ muzejním prostředí. $\mathrm{V}$ rovině individuální pomáhá rozvíjet osobnostní charakteristiky učícího se, vytvářet podmínky pro konstruování komplexních poznatkových systémů namísto izolovaných vědomostí, podporovat vyšší úrovně osvojování vědomostí, praktických aplikací poznatků, uvědomování si vlastních myšlenkových postupů a rozvíjet samostatné práce se zdroji informací. ${ }^{60} \mathrm{Na}$ úrovni sociální pak vytváří podmínky k učení v reálných situacích, jež jsou situacemi každodenního života, stimuluje ke skupinovému konstruování poznatků, objevování, uvědomování a řešení problémů, překonávání překážek, formování verbálního projevu, rozvíjení schopnosti dorozumívání a kooperace s ostatními a společným diskuzím nad aspekty vlastní kultury i rozmanitostmi cizích kultur. ${ }^{61}$

Přestože dosud chybí kvantifikující empirické výzkumy, které by potvrdily efektivitu výše uvedeného u dostatečného vzorku takto vzdělávaných, respektive učících se jedinců, zcela jednoznačný př́ínos konstruktivismu spočívá v epistemologickém názoru, že samotný poznatek se utváŕí $\mathrm{v}$ myšlení jedince, $\mathrm{v}$ němž je

\footnotetext{
60 Výčet pozitiv konstruktivistické výuky podle ŠKODA, Jiří a Pavel DOULÍK. Psychodidaktika: metody efektivního a smysluplného učení a vyučování. Praha: Grada, 2011.

61 Viz BERTRAND, Yves. Soudobé teorie vzdělávání. Praha: Portál, 1998, s. 135.
}

i konstruován a s ním souvisejícím tvrzením, že „učení je aktivní proces".

Praktické didakticko-metodologické uchopení konstruktivismu v muzejní edukaci, dokládající popsané výhody alespoň v potenciální rovině, ilustrují dva edukační programy, realizované $\mathrm{v}$ prostorách bývalých továren. S oporou o výsledky kvalitativního výzkumného šetření, které zde nebyly pro rozsah práce i záměr autorky blíže specifikovány, lze konstatovat, že obě tzv. nová průmyslová muzea naplňují požadavky konstruktivistického typu muzea jak v rovině výstavní didaktiky dle popisu George Heina, tak v oblasti prezentační didaktiky. Již svou specifickou koncepcí, zaměřenou nikoliv na sérii chronologicky uspořádaných strojů a prezentaci technického a technologického vývoje, nýbrž na dějiny každodennosti dělníků, předkládané v podobě srozumitelných př́běhů skrze autenticitu hmotné kultury a doplňující explikační, referenční či substituující prvky, obě muzea konstruktivistické zásady reflektují. Na příkladu edukačních programů, respektive jejich podstatné části, jíž byla práce žáků s pracovními listy, bylo nastíněno konstruktivistické pojetí prezentačně didaktické nabídky uvedených muzeí.

$\mathrm{V}$ obou případech se jednalo o skupinovou práci, v rámci níž žáci ve věku 13 (Oberhausen) až 15 (Bocholt) let společně v roli vybrané postavy konstruovali poznatky i reálné historické př́iběhy z prostředí dvou továrních podnikù. Oporou jim v tom byly pracovní listy, které plnily organizačněregulativní, aktivizačně-motivační a informativní (pouze Bocholt) funkci, poskytující návod $\mathrm{k}$ interakci $\mathrm{s}$ př́ślušnými muzeáliemi, exponáty nemuzeální hodnoty, písemnými a vizuálními prameny či jinými didaktickými prostředky. 
Jeden ze základních faktorů konstruktivistického učení, jemuž protagonisté konstruktivistických teorií přisuzují zásadní roli zjištování prekonceptů žáků - byl součástí úvodní evokace obou programů. Hlavní fáze skupinové práce měla charakter objektového, zážitkového a badatelského učení, při němž se žáci kromě osvojování znalostí a v několika případech i dovedností učili vzájemné spolupráci, naslouchání druhým, vzájemné komunikaci, skrze objevená fakta také empatii $s$ historickými postavami (učeň Wilhelm - Bocholt; učeň, dělník, mistr - Oberhausen), přemýšlet nad lidskými hodnotami a postoji. Při plnění úkolů byli nenásilnou formou vedeni $\mathrm{k}$ složitějším i tvůrčím myšlenkovým operacím. Stejnou váhu jako uvědomování si dosavadních znalostí a představ o období průmyslové revoluce, životních a pracovních podmínkách dělníků či dopadu průmyslové výroby na životní prostředí měla na konci programů závěrečná prezentace skupin s diskuzí.

\section{Phillipsovy předpoklady} konstruktivistického učení, jimiž je aktivní získávání poznatků, vytvářené a kreativně (re) konstruované v dialogu s druhými, tak oba z programů náležitě naplnily.

\section{SEZNAM POUŽITÝCH ZDROJŮ A LITERATURY:}

BERTRAND, Yves. Soudobé teorie vzdělávání. Praha: Portál, 1998. ISBN 80-7178-216-5.

BROWN, Ann L. The Advancement of Learning. Educational Researcher, 1994, roč. 23, č. 8, s. 4-12. ISSN 0013-189X. https://doi.org/10.3102/0013189X023008004 GEBHARD, Julius. Alfred Lichtwark und die Kunsterziehungsbewegung in Hamburg. Hamburg: Hoffmann und Campe, 1947. GEELAN, David R. Epistemological Anarchy and the Many Forms of Constructivism. Science and Education, 1997, roč. 6, č. 1, s. 15-28. ISSN 1573-1901.
HEIN, George E. The constructivist museum. In HOOPER-GREENHILL, Eilean. The Educational Role of the Museum. London, New York: Routledge, 1994, s. 76-77. ISBN 0-415-19826-7.

HEJL, Peter M. Die zwei Seiten der Eigengesetzlichkeit: Zur Konstruktion natürlicher Sozialsysteme und zum Problem ihrer Regelung. In SCHMIDT, Siegfried J. (ed.). Kognition und Gesellschaft. Der Diskurs des Radikalen Konstruktivismus II. Frankfurt am Main: Suhrkamp, 1992, s. 116-145. ISBN 987-3-518-28550-3.

HEMINGWAY, Ernest. Komu zvoní hrana. Praha: Odeon, 2016. ISBN 978-80-207-1682-8.

Karl Ernst Osthaus - Leben und Werk. Recklinghausen: Bongers, 1971. ISBN 3-7647-0223-0.

JOACHIMEDES, Alexis. Die Museumsreformbewegung in Deutschland und die Entstehung des modernen Museum 1880-1940. Dresden: Verlag der Kunst, 2001. ISBN 90-5705-171-0.

JŮVA, Vladimír. Vývoj německé muzeopedagogiky. Brno: Paido, 1994. ISBN 80-901737-2-1.

KAŠČÁK, Ondrej. Je pedagogika připravená na změny perspektiv? Rekontextualizace pohledů na výchovně-vzdělávací proces pod vlivem radikálního individuálního konstruktivismu a postmoderního sociálního konstruktivismu. Pedagogika, 2002, roč. 52, č. 4, s. 388-414. ISSN 0031-3815.

KERSCHENSTEINER, Georg. Die Bildungsaufgabe des Deutschen Museums. In MATSCHOSS, Conrad (ed.). Das deutsche Museum, Geschichte, Aufgaben, Ziele; im Auftrage des Vereines Deutscher Ingenieure unter Mitwirkung hervorragender Vertreter der Technik und Naturwissenschaften. Berlin: VDI Verlag, München: R. Oldenbourg, 1925, s. 39-50.

KOLAŘÍKOVÁ, Veronika. Konstruktivistické teorie učení a jejich využití v edukační realitě muzea. Pedagogická orientace, 2018, roč. 28, č. 3, s. 496-540. ISSN 1211-4669.

https://doi.org/10.5817/PedOr2018-3-496 KRPEC, Radek. Konstruktivistický př́stup $k$ výuce kombinatoriky. Ostrava: Ostravská univerzita v Ostravě, 2016. ISBN 978-80-7464-892-2.
KUHN, Anja. Käpt'n Henri und Co. Von Schrittmachern und Stolpersteinen der Museumspädagogik im Westfälischen Industriemuseum. Standbein Spielbein. Museumspädagogik aktuell, 2002, sv. 62, s. 25. ISSN 0936-6644.

KUPFFER, Heinrich. Pädagogik der Postmoderne. Weinheim: Beltz, 1990. ISBN 978-3-407-34035-1.

MATURANA, Humberto R. a Francisco J. VALERA. Der Baum der Erkenntnis: Die biologischen Wurzeln des Menschlichen Erkennens. München: Goldmann, 1990. ISBN 978-3-442-11460-3.

MIKULÁŠKOVÁ, Monika. Proměny konstruktivismu v muzejní pedagogice George E. Heina. Museologica Brunensia, 2017, roč. 6, č. 1, s. 41-47. ISSN 1805-4722.

https://doi.org/10.5817/MuB2017-1-5

PARENT, Thomas. Das Westfälisches Industriemuseum Dortmund Anmerkungen zu den Chancen und Problemen der Musealisierung von Industriedenkmälern. In VOGT, Arnold a Hans-Ulrich NIEMITZ (eds.). Technik - Faszination und Bildung. Impulse zur Museumpraxis, Didaktik und Museologie. München: Verlag Dr. Christian Müller-Straten, 2008. ISBN 978-3-932704-79-6.

PETTY, Geoffrey. Moderní vyučování. Praha: Portál, 2008. ISBN 978-80-7367-4.

PUPALA, Branislav a L'ubica OSUSKÁ. Vývoj, podoby a odkazy teorie konštruktivizmu. Pedagogická revue, 2002 , roč. 52 , č. 2 , s. 101-114. ISNN 1335-1982.

RORTY, Richard. Holizmus, interiorizmus a ambícia transcendencie. Filozofia, 1993, roč. 48, č. 4, s. 226-241. ISSN 0046-385X.

ROTH, Gerhard. Das konstruktive Gehirn: Neurobiologische Grundlagen von Wahrnehmung und Erkenntnis. In SCHMIDT, Siegfried J. (ed.). Kognition und Gesellschaft. Der Diskurs des Radikalen Konstruktivismus II. Frankfurt am Main: Suhrkamp, 1992, s. 277-336. ISBN 978-3-518-28550-3.

ROTH, Wolff-Michael a Anita ROYCHOUDHURY. The Social Construction of Scientific Concepts or the Concept Map as Conscription Device and Tool for Social Thinking in High School Science. Science Education, 1992, roč. 76, 


\section{č. 5, s. 531. ISSN 1098-237X.}

https://doi.org/10.1002/sce.3730760507

SCHÜRENKAMP, H. J. Wilhelms Arbeitstag in der Fabrik. Arbeitsplatz Webstuhl. LWL Industriemuseum, Textilmuseum in Bocholt, 2003. [nepublikováno].

Socialer Konstruktivismus - eine neue Perspektive in der Psychologie. In SCHMIDT, Siegfried J. (ed.). Kognition und Gesellschaft. Der Diskurs des Radikalen Konstruktivismus II. Frankfurt am Main: Suhrkamp, 1992, s. 116-145. ISBN 987-3-518-28550-3.

STEINERT, Arne. Konzepte der Musealisierung von Technik und Arbeit. In VOGT, Arnold a Hans-Ulrich NIEMITZ (eds.). Technik - Faszination und Bildung. Impulse zur Museumspraxis, Didaktik und Museologie. München: Verlag Dr. Christian Müller-Straten, 2008. ISBN 978-3-932704-79-6.

ŠIMÍK, Ondřej. Utváření obsahu př́rodovědné výuky na 1. stupni ZŠ $v$ konstruktivistickém pojetí - výzkum tematického celku VODA. Ostrava:
Ostravská univerzita v Ostravě, 2012. ISBN 978-80-7464-223-4.

ŠKODA, Jiří a Pavel DOULÍK. Dětská pojetí: teoretická východiska a metodologické aspekty. In JANÍKOVÁ, Marcela a Kateřina VLČKOVÁ. Výzkum výuky - tematické oblasti, výzkumné př́stupy a metody. Brno: Paido, 2009, s. 117-143. ISBN 978-80-7315-180-5.

ŠKODA, Jiří a Pavel DOULÍK. Psychodidaktika: metody efektivního a smysluplného učení a vyučování. Praha: Grada, 2011. ISBN 978-80-247-3341-8.

VIEREGG, Hildegard. Geschichte des Museums, eine Einführung. München: Wilhelm Fink Verlag, 2008. ISBN 978-3-7705-4623-7.

WHEATLEY, Grayson H. Constructivist Perspectives on Science and Mathematics Learning. Science Education, 1991, roč. 75 , č. 1, s. 9-21. ISSN 1098-237X. https://doi.org/10.1002/sce.3730750103

\section{MONIKA KUDELOVÁ}

Katedra historie, Filozofická fakulta, Ostravská univerzita v Ostravě, Česká republika

a16618@student.osu.cz

Monika Kudelová je studentka doktorského studijního programu na Katedře historie na Filozofické fakultě Ostravské univerzity. V současné době se zaměřuje na muzejní didaktiku, didaktiku dějepisu a mimoškolní formy výuky.

Monika Kudelová is doctoral student in the Department of History, Faculty of Arts, University of Ostrava. She is currently oriented on museum didactics, didactics of history teaching and the forms of extracurricular education. 